\title{
Reading Strategies Employed by University Business English Majors with Different Levels of Reading Proficiency
}

\author{
Jun Chen $^{1} \&$ Channarong Intaraprasert ${ }^{1}$ \\ ${ }^{1}$ School of Foreign Languages, Institute of Social Technology, Suranaree University of Technology, Thailand \\ Correspondence: Jun Chen, Surasammanakhan Hotel, Suranaree University of Technology, 111 University \\ Avenue, Muang District, Nakhon Ratchasima 30000, Thailand. Tel: 86-139-8507-6070. E-mail: \\ darrenchenjun@163.com
}

Received: January 23, 2014 Accepted: February 24, 2014 Online Published: March 6, 2014

doi:10.5539/elt.v7n4p25 URL: http://dx.doi.org/10.5539/elt.v7n4p25

\begin{abstract}
The purpose of this study was to investigate the use of reading strategies by the university Business English majors in relation to their levels of reading proficiency. The participants were 926 university Business English majors from 6 universities in southwest China. The Strategy Questionnaire for Business English Reading (SQBER) and the Business English Reading Comprehension Test (BERCT) were used to collect the data. The results showed that the students with good reading proficiency reported significantly greater use of reading strategies than the students with either fair or poor reading proficiency at the overall and category levels. At the individual strategy level, 25 out of the 45 reading strategies across the inventory varied significantly in terms of the students' levels of reading proficiency. Most of these strategies with significant differences showed positive correlation, with the higher reading proficiency students reporting employing reading strategies significantly more frequently than the lower reading proficiency students. In addition, the students with different proficiency levels had different tendencies in the use of individual reading strategies.
\end{abstract}

Keywords: reading strategies, reading proficiency, Business English majors

\section{Introduction}

"Reading is the process of receiving and interpreting information encoded in language form via the medium of print." (Urquhart \& Weir, 1998, p. 22). It is an active and fluent process which involves the reader and the reading material in building meaning (Anderson, 1999). It starts with a linguistic surface representation encoded by a writer and ends with the meaning which the reader constructs (Goodman, 1995). Reading plays a crucial role in language learning. For many students, reading is by far the most important of the four skills in a second language, particularly in English as a second or foreign language (Carrel, Devine, \& Eskey, 1998). It is through reading that the language learners access a large amount of information concerning the target language and culture. Adamson (1993) also asserts that of all the language skills, it is accepted that reading is the most important skill for academic achievement when compared with the other language skills. According to Badrawi (1992, p. 16), "Reading is a helpful language skill needed for obtaining information, fostering and reacting to ideas, developing interests, and finally deriving pleasure by reading through understanding or comprehension." Effective and efficient reading is the prerequisite for successful language learning.

To achieve effective or desired results of reading, reading strategies play a critical role. Reading strategies are "deliberate, cognitive steps that readers can take to assist in acquiring, storing and retrieving new information" (Anderson, 1991, p. 460). They are the ways of reading which the readers employ flexibly and selectively, and they vary according to the text-type, the context and the purpose of reading (Wallace, 1992). They are a set of abilities under the conscious control of the reader (Grabe \& Stoller, 2007). Both reading in L1 and L2 involve the use of various strategies that assist readers to understand the reading materials (Carrel, 1991). Reading strategies are very useful and important in reading comprehension. As Song (1998) points out, reading strategies are important because they help learners to improve their reading comprehension, and to enhance efficiency in reading. Strategic awareness is a critically important aspect of skilled reading. The strategic readers are believed to draw on a variety of strategies to accomplish the purpose in reading. Researchers have long recognized that reading strategies are strongly associated with the success of reading. Effective readers are more aware of strategy use than less effective readers. Empirical studies indicate that the success in reading is linked to the 
quality and quantity of reading strategies used (Oxford, 1989; Brown, 1989; Alderson, 2000).

As one of the main factors that may affect the results of reading, reading strategies have been given continuous attention by researchers since the 1970s. Many researchers (e.g. Hosenfield, 1977; Block, 1986; Barnett, 1988; Anderson, 1991; Anderman, 1992; Sheory \& Mokhtari, 2001; Anastasiou \& Griva, 2009; Saengpakdeejit, 2009; Maarof \& Yaacob, 2011) have conducted studies to investigate the relationship between learners' levels of reading proficiency and their use of reading strategies. This line of research has investigated to what extent skilled reading is different from less skilled reading. Block (1986) used think-aloud protocols and verbal report to examine the reading strategies used by 9 university level ESL and native English students in a remedial reading course. The results showed that more successful readers used their general knowledge; focused on the overall meaning of text; integrated new information with old; differentiated main ideas from the supporting points, while, the poor readers rarely did any of the above. Anderson (1991) carried out a study to investigate the individual differences of reading strategies employed by adult second language learners. The results from his study showed that both successful and unsuccessful readers seemed to use the same pattern of reading strategies, but successful readers appeared to apply reading strategies more effectively and appropriately. Sheorey and Mokhtari (2001) examined the differences in reading strategies employed by the US and ESL students when reading academic materials, with the results revealing that both US and ESL high-reading-ability students showed comparable degrees of higher reported usage for metacognitive and cognitive reading strategies than lower-reading-ability students in the respective groups. Anastasiou and Griva's study (2009) revealed that poor readers were less aware of the more sophisticated cognitive strategies, and that they used a limited number of metacognitive strategies in comparison with good readers. Similarly, the study by Maarof and Yaacob (2011) showed that advanced proficiency students used more reading strategies in L2 when compared with the other group of students.

In China, studies on reading strategies are very few. Only a few researchers have carried out some empirical studies to investigate whether there were correlation between the EFL learners' levels of reading proficiency and their use of reading strategies (Liu, 2002; Liu, 2004; Liu \& Zhang, 2008; Zhang \& Wu, 2009; Luo, 2010). Liu's (2002) study used 193 non-English major participants to compare the difference between the strategies used by successful readers and unsuccessful readers. The results showed that among the 45 reading strategies, 11 reading strategies existed significant differences between the successful readers and unsuccessful readers. Successful readers reported using more metacognative strategies than unsuccessful readers. Liu (2004) conducted a research with 64 English-major students to investigate the relationships between metacognitive reading strategies and English reading proficiency. The results showed that there was a positive relationship between the frequency of overall metacognive strategy use and reading achievements. Liu and Zhang (2008) compared the difference of reading strategy use between successful readers and unsuccessful readers using 202 non-English majors as participants. The results showed that there was correlation between the cognitive strategy use and the students' performance on reading. Successful readers used reading strategies more frequently than less successful ones. In accordance, Luo (2010) also found that students with higher reading proficiency reported employing reading strategies significantly more frequently than the students with lower reading proficiency.

Although Business English teaching in China has a history of over 50 years, the development in this area is still not up to par satisfactory. The experience of teaching and learning Business English is still lacking, especially in the underdeveloped Southwest China. After years of Business English learning, many students still can not read Business English materials efficiently and effectively. Therefore, it is worthy and necessary to conduct research to investigate the reading strategies employed by the university Business English majors so as to improve their academic reading abilities. Through an extensive review of the literature, no empirical studies have been carried out specifically to investigate the use of reading strategies by university Business English majors in China. Therefore, the present study was intended to fill in this gap. It aimed to examine whether there were correlations between the use of reading strategies by the university Business English majors in Southwest China and their levels of reading proficiency. The research questions were: 'Do the reading strategies employed by university Business English majors vary significantly in terms of their levels of reading proficiency at the overall, category and individual levels? If they do, what are the main patterns of variation?'

\section{Research Methodology}

\subsection{Key Terms Used in the Present Study}

\subsubsection{Business English Majors}

"Business English majors" in the present study refers to the university students majoring in the business-oriented English program. This program is a content-based instruction (CBI) program. The students of this program are 
required to learn the English language in the context of international business communication as well as master the content knowledge of international trade and economics using English as the medium.

\subsubsection{Reading Strategies}

"Reading strategies" in the present study is defined as the skills, techniques, methods and behaviors that the university Business English majors employ to enhance their reading comprehension or solve their reading problems and difficulties when reading Business English texts.

\subsubsection{Level of Reading Proficiency}

In this study, "level of reading proficiency" refers to the reading ability of the Business English majors in reading Business English, which was assessed according to their scores in the Business English reading test. The students' levels of reading proficiency were classified as 'good', 'fair' and 'poor' based on their scores in the test.

\subsection{Participants}

The participants for the present study were the university Business English majors from Southwest China. As it was a large-scale survey study and not many universities in Southwest China offer the Business English program, the researcher decided to use the cluster sampling method and then the purposive sampling method to select the participants. The population of the present study was divided into three clusters: Guizhou Province, Yunnan Province and Chongqing City. The researcher first selected two universities from each cluster. The participants were then purposively chosen from each of the universities based on convenience and availability. Among the 926 participants selected for the present study, 312 students were from Guizhou Province, 310 students were from Yunnan Province and 304 students were from Chongqing City. Forty-eight participants were selected for the semi-structured interviews to explore the reasons why they employed certain strategies frequently and certain strategies infrequently.

\subsection{Data Collection}

Two instruments were used to collect the data for the present investigation. One was the Strategy Questionnaire for Business English Reading (SQBER), which was designed to elicit the participants' use of reading strategies. The other instrument was the Business English Reading Comprehension Test (BERCT), which was constructed to determine the participants' levels of reading proficiency.

\subsubsection{Strategy Questionnaire for Business English Reading}

The Strategy Questionnaire for Business English Reading (SQBER) was designed by the researcher mainly based on the studies of Anderson (1991), Sheorey and Mokhtari (2001), Mokhtari and Reichard (2002), Taraban, Kerr, and Rynearson (2004), Cheng (2010), Luo (2010). The researcher carefully selected 37 strategy items from these studies and did some modification to compose a more comprehensive questionnaire. The initial questionnaire consisted of both close and open-ended questions. The close-ended questions were composed of the 37 selected strategy items. This was followed by one open-ended question, which gave the participants the freedom to list the reading strategies they often used but were not included in the questionnaire. The strategy items were classified into 3 categories, i.e. 1) the Pre-reading Strategies (PRS), 2) the While-reading Strategies (WHS), and 3) the Post-reading Strategies (POS). The While-reading Strategies (WHS) were further divided into two sub-categories of the Strategies for Comprehending the Text (SCT) and the Strategies for Coping with Difficulties (SCD). A 4-point rating scale adopted from Intaraprasert (2000) was used to value the frequency of the strategy use by the participants. The scales were valued as 1,2,3, and 4, which represent "Never", "Sometimes", "Often" and "Always/Almost always". The initial questionnaire was piloted with 180 university Business English majors, who were excluded in the main study. Among them 10 students were selected for the interviews. The internal reliability estimate of Alpha Coefficient $(\alpha)$ of the questionnaire was .87 in the pilot study. After the pilot study, some strategy items were modified based on the feedback of the participants. Five strategies emerged from the open-ended question in the questionnaire and three strategies that emerged from the interviews were carefully selected to add into the reading questionnaire. In the end, the final version of the reading questionnaire for the main study consisted of 45 strategy items. The estimated reliability $(\alpha)$ based on the 926 participants in the main study was .91 , which was much higher than the acceptable reliability coefficient of .70 .

\subsubsection{Business English Reading Comprehension Test}

The Business English Reading Comprehension Test (BERCT) was constructed by the researcher through selecting the reading texts from the authentic BEC (Business English Certificate) tests, including the three levels 
of Preliminary, Vantage and Higher. The BEC is a collaborative program between the Chinese National Education Examinations Authority (NEEA) and the University of Cambridge Local Examinations Syndicate (UCLES). It has been designed to test language learners' English language abilities in the business context. The BEC tests have been well recognized and widely accepted in China. The initial BERCT comprised seven parts (seven different reading tasks), consisting of 61 question items. After the BERCT had been constructed, it was piloted together with the questionnaires mentioned above. Item analysis was used to examine the quality of the question items. Based on the results of the item analysis, five question items were removed because their facility values were either too high or too low and the power of discrimination was extremely low. As a result, the final version of the BERCT for the main study consisted of 56 question items. The split-half procedure was used to test the reliability of the reading test in the main study. The results revealed that the reliability of the test was .89, which was considered acceptable as it was higher than the acceptable criterion of .70 proposed by Fraenkel and Wallen (2000). Based on the students' scores obtained in the reading test, the reading proficiency of the participants was classified as three levels of "good", "fair" and "poor".

\subsection{Data Analysis}

The data obtained from the questionnaires and the reading test was inputted into the computer, and then the SPSS program was conducted to analyze the data. The statistical methods used in the present study included the ANOVA (Analysis of Variance), the Post-hoc Scheffe Test, and the Chi-square test. The ANOVA was employed to examine the variations of the students' strategy use at the overall and category levels. The Post-hoc Scheffe Test was used to determine the variations of the strategy use between the students with different reading proficiency levels if significant differences were found in the ANOVA. The Chi-square test was employed to examine the variations of the students' use of reading strategies at the individual strategy level.

\section{Results}

The following are the findings of the present study. The results are reported in a top-down manner. That is, the variations in the frequency of students' strategy use according to their levels of reading proficiency are presented from their overall strategy use, to strategy use in categories and finishing with individual strategy use.

\subsection{Variations in Frequency of Students' Overall Reading Strategy Use}

The variations in the frequency of students' overall reading strategy use are presented in Table 1 below, which consists of the variable, the number of students, the mean frequency score (mean), the standard deviation (S.D.), the significant level and the variation pattern. The results of ANOVA showed that the students' reported overall reading strategy use varied significantly according to their levels of reading proficiency $(\mathrm{P}<.01)$. The Post hoc Scheffe Tests revealed that significant variations existed between the students with good reading proficiency and the students with fair reading proficiency (The mean scores of the two groups were 2.45 and 2.37 respectively), and also existed between the students with good reading proficiency and the students with poor reading proficiency (the mean scores of the two groups were 2.45 and 2.38 respectively). No significant differences in strategy use were found between the students with fair and poor proficiency. This indicates that the students with good proficiency employed reading strategies significantly more frequently than either the students with fair proficiency or the students with poor proficiency at the level of overall strategy use.

Table 1. Variations in frequency of students' overall reading strategy use

\begin{tabular}{lcccccc}
\hline Variable & & Number & Mean & S.D. & Sig. Level & Variation Pattern \\
\hline \multirow{2}{*}{ Level of Reading } & Good & 294 & 2.45 & .34 & & Good $>$ Fair \\
Proficiency & Fair & 325 & 2.37 & .35 & $\mathrm{P}<.01$ & Good $>$ Poor \\
& Poor & 307 & 2.38 & .32 & & \\
\hline
\end{tabular}

\subsection{Variations in Frequency of Students' Strategy Use in the Categories}

As shown in Table 2, significant variations in the students' use of reading strategies in the WHS category were found according to the students' levels of reading proficiency. The Post hoc Scheffe Tests revealed that the students with good proficiency reported significantly greater use of reading strategies than the students with poor proficiency $(\mathrm{P}<.05)$. However, the strategy use of the students with fair proficiency was not significantly different from that of the students with good or poor proficiency in this category. For all this, the frequency mean score of the students with fair proficiency was slightly lower than that of the students with good proficiency and 
slightly higher than that of the students with poor proficiency. The main tendency was that the students with higher proficiency levels employed more reading strategies than the students with lower proficiency levels. No significant variations were found in the PRS and POS categories in terms of this variable. This means that the differences of reading strategy use between the students with different proficiency levels mainly existed in the while-reading phase, not in the pre-reading and post-reading phases at the category level.

Table 2. Variations in frequency of students' reading strategy use in the categories

\begin{tabular}{lllllllll}
\hline \multirow{2}{*}{ Strategy Category } & \multicolumn{2}{l}{ Good $(\mathrm{n}=294)$} & \multicolumn{2}{l}{ Fair $(\mathrm{n}=325)$} & \multicolumn{2}{l}{ Poor $(\mathrm{n}=307)$} & \multirow{2}{*}{ Sig. Level } & Variation \\
\cline { 2 - 6 } & Mean & S.D. & Mean & S.D. & Mean & S.D. & & Pattern \\
\hline PRS Category & 2.50 & .41 & 2.46 & .41 & 2.51 & .38 & N.S. & ----- \\
WHS Category & 2.54 & .35 & 2.47 & .33 & 2.45 & .33 & P<.05 & Good $>$ Poor \\
POS Category & 2.26 & .43 & 2.20 & .46 & 2.22 & .45 & N.S. & ----- \\
\hline
\end{tabular}

Note: "N.S" stands for "No Significance"

As presented above, the students' use of reading strategies varied significantly in the WHS category according to their levels of reading proficiency. Further analysis was conducted to examine whether variations existed in the sub-categories of WHS. Table 3 demonstrates the results of the analysis. It showed that the students' use of reading strategies in the SCT sub-category varied significantly according to their levels of reading proficiency. The variation pattern was positive, i.e. the mean frequency score of the students with good proficiency was significantly higher than that of the students with fair proficiency, and the mean frequency score of the students with fair proficiency was significantly higher than that of the students with poor proficiency. No significant differences were found in the SCD sub-category. This implies that although there were significant differences in the students' use of reading strategies in the WHS category according to the students' levels of reading proficiency, the actual differences only existed in the SCT sub-category.

Table 3. Variations in frequency of students' reading strategy use in the sub-categories

\begin{tabular}{lllllllll}
\hline \multirow{2}{*}{ Sub- Category } & \multicolumn{2}{l}{ Good $(\mathrm{n}=294)$} & \multicolumn{2}{l}{ Fair $(\mathrm{n}=325)$} & \multicolumn{2}{l}{ Poor $(\mathrm{n}=307)$} & \multirow{2}{*}{ Sig. Level } & \multirow{2}{*}{ Variation Pattern } \\
\cline { 2 - 7 } & Mean & S.D. & Mean & S.D. & Mean & S.D. & & \\
\hline SCT Category & 2.61 & .39 & 2.52 & .38 & 2.46 & .38 & P $<.01$ & \multirow{2}{*}{ Good $>$ Fair $>$ Poor } \\
SCD Category & 2.45 & .37 & 2.40 & .36 & 2.41 & .34 & N.S. & - ---- \\
\hline
\end{tabular}

\subsection{Variations in Frequency of Students' Individual Strategy Use}

As reported in Section 3.1 and 3.2, the frequency of the students' overall reading strategy use and use of reading strategies in the WHS category and the SCT sub-category of WHS varied significantly according to the students' levels of reading proficiency. After presenting the variations at the first two levels, i.e. the overall and category, this section further presents the variations of the students' reading strategy use in relation to their reading proficiency by looking at their individual strategy use by using the Chi-square Tests. The results are presented in order of the percentage of the high use of the reading strategies by the students ( 3 and 4 in the strategy questionnaire), ranking from the highest to the lowest in each variation pattern. This made it easier to see an overall picture of the reading strategies which were reported to be frequently used by the students. Table 4 demonstrates the results of the Chi-square Tests, including the percentage of the high use of reading strategies by the students with different proficiency levels, the observed Chi-square value $\left(\chi^{2}\right)$ and the pattern of variation.

The results of the Chi-square Tests in Table 4 showed that more than half of the reading strategies in the questionnaire (25 out of 45 ) varied significantly according to the students' levels of reading proficiency. Of the 25 items showing significant differences according to this variable, 18 belong to the WHS category; only 4 and 3 strategies belong to the PRS and POS categories respectively. This indicates that the use of reading strategies by the students with different levels of reading proficiency varied mainly in the actual reading phase. In other words, it was the use of the reading strategies in the actual while-reading stage that distinguished the good and poor readers. This was in line with the results of ANOVA at the category level, in which variations only existed in the 
WHS category. The results of the Chi-square Tests showed that the students' use of reading strategies seemed to have strong correlation with their levels of reading proficiency, as a large proportion of individual reading strategies across the strategy inventory varied significantly in terms of this variable. Of the 25 individual strategies showing significant differences, more than half of the students with good reading proficiency reported high use of 13 of these strategies; more than half of the students with fair reading proficiency reported high use of 12 of these strategies; and more than half of the students with poor reading proficiency reported high use of 7 of these strategies.

Regarding the variation patterns of the students' reading strategy use, as Green and Oxford (1995) suggested, it may be positive (used more by higher-proficiency students), negative (used more by lower-proficiency students), or mixed. In the present investigation, of the 25 individual strategies showing significant variations, 17 strategies were classified as positive (good $>$ moderate>poor), in which a significantly greater percentage of the students at the higher reading proficiency level than the student at the lower proficiency level reported high use of these strategies. The top three strategies of this pattern (according to the percentage of high use) are WHS15 (Guess the meanings of the words or the sentences from the context), WHS17 (Adjust the reading rate accordingly) and WHS1 (Pay attention to the key words in the text). Six strategies were classified as negative (poor $>$ moderate $>$ good), in which a significantly greater percentage of the students at the lower proficiency level than the students at the higher proficiency level reported high frequency use of these strategies. Example are PRS4 (Read/check the new word list), WHS21 (Consult the dictionary for new words while reading) and WHS19 (Translate the text into Chinese). Two strategies (WHS22 and WHS9) were classified as mixed (fair>good>poor), in which a significantly greater percentage of the students with fair proficiency than the students with good proficiency reported high frequency use of the two strategies, and a greater percentage of the students with good proficiency students than the students with poor proficiency students reported high use of the two strategies.

The results of the Chi-square Tests revealed that the students at the higher proficiency level reported employing the individual reading strategies significantly more frequently than the students at the lower proficiency level. It was also found that the students with different proficiency levels tended to employ different reading strategies. For example, the students with good proficiency tended to use the strategies relating to guessing (e.g. WHS15. Guess the meaning of the words or sentences from the text), holistically comprehending the text (e.g. PRS8. Skim the text and WHS13. Do fast reading first and peruse later), seeking key information (e.g. WHS1. Pay attention to the key words in the text and WHS12. Skip or neglect the unneeded or unimportant content), regulating the reading process (e.g. WHS17. Adjust the reading rate accordingly and PRS3. Set goals/purposes of reading), and using linguistic knowledge (e.g. WHS20. Make use of word collocations and WHS16. Analyze the structures of difficult sentences). Whereas, the students with poor reading proficiency tended to employ the strategies relating to dealing with the new words (e.g. PRS4. Read or check the new word list and WHS21. Consult the dictionary for new words) and the strategies relating to seeking help from others (WHS18. Ask the teachers, classmates or friends for help and POS10. Discuss the problems or difficulties with teachers or friends).

Table 4. Variations in frequency of students' individual strategy use

\begin{tabular}{|c|c|c|c|c|c|}
\hline \multirow{2}{*}{$\begin{array}{l}\text { Individual Learning Strategy } \\
\text { Positive: good }>\text { fair>poor (17 strategies) }\end{array}$} & \multicolumn{3}{|c|}{$\%$ of high use ( 3 and 4$)$} & \multirow{2}{*}{$\begin{array}{l}\text { Observed } \chi^{2} \\
\mathrm{P}<.05\end{array}$} & \multirow{2}{*}{$\begin{array}{l}\text { Variation } \\
\text { Pattern }\end{array}$} \\
\hline & Good & Fair & Poor & & \\
\hline $\begin{array}{l}\text { WHS15. Guess the meanings of the words or the } \\
\text { sentences from the context }\end{array}$ & 71.1 & 66.8 & 59.9 & $\chi^{2}=8.49 *$ & $\mathrm{G}>\mathrm{F}>\mathrm{P}$ \\
\hline WHS17. Adjust the reading rate accordingly & 69.0 & 59.4 & 51.5 & $\chi^{2}=19.35^{* * *}$ & $\mathrm{G}>\mathrm{F}>\mathrm{P}$ \\
\hline WHS1. Pay attention to the key words in the text & 66.0 & 63.5 & 56.0 & $\chi^{2}=8.30 *$ & $\mathrm{G}>\mathrm{F}>\mathrm{P}$ \\
\hline PRS6. Read the questions about the text & 65.1 & 53.2 & 41.3 & $\chi^{2}=13.65^{* *}$ & $\mathrm{G}>\mathrm{F}>\mathrm{P}$ \\
\hline WHS13. Do fast reading first and peruse later & 63.7 & 51.3 & 42.5 & $\chi^{2}=8.83^{*}$ & $\mathrm{G}>\mathrm{F}>\mathrm{P}$ \\
\hline $\begin{array}{l}\text { WHS10. Take notes or mark the important } \\
\text { information in the text }\end{array}$ & 61.2 & 56.3 & 51.3 & $\chi^{2}=7.65^{*}$ & $\mathrm{G}>\mathrm{F}>\mathrm{P}$ \\
\hline WHS7. Make use of the features of the text & 60.6 & 58.5 & 49.5 & $\chi^{2}=8.79 *$ & $\mathrm{G}>\mathrm{F}>\mathrm{P}$ \\
\hline PRS8. Skim the text & 59.0 & 55.8 & 47.7 & $\chi^{2}=8.62 *$ & $\mathrm{G}>\mathrm{F}>\mathrm{P}$ \\
\hline WHS2. Use specialized terms as clues or indications. & 57.5 & 49.5 & 46.5 & $\chi^{2}=7.27 *$ & $\mathrm{G}>\mathrm{F}>\mathrm{P}$ \\
\hline
\end{tabular}




\begin{tabular}{|c|c|c|c|c|c|}
\hline $\begin{array}{l}\text { WHS12. Skip or neglect the unneeded or unimportant } \\
\text { content }\end{array}$ & 55.4 & 51.4 & 45.9 & $\chi^{2}=7.51^{*}$ & $\mathrm{G}>\mathrm{F}>\mathrm{P}$ \\
\hline PRS3. Set goals or purposes of reading & 54.4 & 47.1 & 44.6 & $\chi^{2}=6.23$ & $\mathrm{G}>\mathrm{F}>\mathrm{P}$ \\
\hline WHS20. Make use of word collocations. & 52.0 & 44.0 & 40.0 & $\chi^{2}=9.29 *$ & $\mathrm{G}>\mathrm{F}>\mathrm{P}$ \\
\hline WHS16. Analyze the structures of difficult sentences & 47.3 & 33.8 & 26.1 & $\chi^{2}=30.14 * * *$ & $\mathrm{G}>\mathrm{F}>\mathrm{P}$ \\
\hline WHS8. Consider the logic, coherence and consistency & 43.5 & 40.6 & 33.6 & $\chi^{2}=6.71^{*}$ & $\mathrm{G}>\mathrm{F}>\mathrm{P}$ \\
\hline POS9. Summarize the mistakes one made & 39.8 & 26.0 & 17.5 & $\chi^{2}=15.8^{* *}$ & $\mathrm{G}>\mathrm{F}>\mathrm{P}$ \\
\hline $\begin{array}{l}\text { POS1. Make critical comments and evaluations on the } \\
\text { content of the text }\end{array}$ & 31.6 & 13.8 & 4.9 & $\chi^{2}=36.82^{* * *}$ & $\mathrm{G}>\mathrm{F}>\mathrm{P}$ \\
\hline $\begin{array}{l}\text { WHS14. Analyze the formations of the unknown } \\
\text { words }\end{array}$ & 24.1 & 17.5 & 13.7 & $\chi^{2}=11.21 * *$ & $\mathrm{G}>\mathrm{F}>\mathrm{P}$ \\
\hline Negative: poor $>$ fair $>$ good ( 6 strategies $)$ & Good & Fair & Poor & $\mathrm{P}<.05$ & $\begin{array}{l}\text { Variation } \\
\text { Pattern }\end{array}$ \\
\hline PRS4. Read or check the new word list & 46.6 & 55.4 & 56.0 & $\chi^{2}=6.69^{*}$ & $\mathrm{P}>\mathrm{F}>\mathrm{G}$ \\
\hline WHS21. Consult the dictionary for new words & 35.7 & 46.3 & 54.2 & $\chi^{2}=13.78^{* *}$ & $\mathrm{P}>\mathrm{F}>\mathrm{G}$ \\
\hline WHS19. Translate the text into Chinese & 33.0 & 44.0 & 47.9 & $\chi^{2}=14.69 * *$ & $\mathrm{P}>\mathrm{F}>\mathrm{G}$ \\
\hline $\begin{array}{l}\text { WHS18. Ask the teachers, classmates or friends for } \\
\text { help }\end{array}$ & 22.1 & 27.4 & 40.7 & $\chi^{2}=26.49 * * *$ & $\mathrm{P}>\mathrm{F}>\mathrm{G}$ \\
\hline $\begin{array}{l}\text { POS10. Discuss the problems or difficulties with } \\
\text { teachers/friends. }\end{array}$ & 21.8 & 26.8 & 33.2 & $\chi^{2}=10.00^{* *}$ & $\mathrm{P}>\mathrm{F}>\mathrm{G}$ \\
\hline $\begin{array}{l}\text { WHS24. Consult references to solve one's reading } \\
\text { problems or difficulties }\end{array}$ & 20.7 & 28.3 & 29.8 & $\chi^{2}=7.40^{*}$ & $\mathrm{P}>\mathrm{F}>\mathrm{G}$ \\
\hline Mixed: fair $>$ good $>$ poor ( 2 strategies $)$ & Good & Fair & Poor & $\mathrm{P}<.05$ & $\begin{array}{l}\text { Variation } \\
\text { Pattern }\end{array}$ \\
\hline WHS22. Reread the difficult parts & 61.6 & 66.8 & 54.4 & $\chi^{2}=10.21^{* *}$ & $\mathrm{~F}>\mathrm{G}>\mathrm{P}$ \\
\hline $\begin{array}{l}\text { WHS9. Draw on one's prior knowledge about the } \\
\text { topic }\end{array}$ & 45.2 & 64.3 & 36.8 & $\chi^{2}=32.33 * * *$ & $\mathrm{~F}>\mathrm{G}>\mathrm{P}$ \\
\hline
\end{tabular}

Notes: $* \mathrm{P}<.05, * * \mathrm{P}<.01, * * * \mathrm{P}<.001$

\section{Discussion}

The findings of the present investigation revealed that the use of reading strategies by the university Business English major students varied significantly according to their levels of reading proficiency at the overall, category and individual levels. As a whole, the students at the higher reading proficiency level reported a significantly higher frequency of reading strategy use. The students with different proficiency levels tended to employ different strategies. The findings of the present study were consistent with many of the previous studies abroad (e.g. Sheorey \& Mokhtari, 2001; Mokhtari \& Reichard, 2004; Martinez, 2008; Cogmen \& Saracaloglu, 2009; Anastasiou \& Griva, 2009; Maarof \& Yaacob, 2011) and also in line with a few studies in the Chinese context (Liu, 2002; Liu \& Zhang, 2008; Zhang \& Wu, 2009; Luo, 2010). The results of these studies revealed that the higher proficiency readers employed reading strategies significantly more frequently than the lower proficiency readers. The higher proficiency readers and the lower proficiency readers had different tendencies in strategy use.

Regarding the differences in the students' reading strategy use in relation to reading proficiency in the present study, a few tentative explanations could be hypothesized to interpret the variations. They are the students' reading motivation, strategic awareness, out-of-classroom reading and language ability. The first explanation could be the students' reading motivation. Motivation is defined by Ellis (1994, p. 715) as "the effort which the learners put into learning an L2 as a result of their need or desire to learn it". According to Ellis (1994, p. 542), motivation is a learner factor that affects learners' use of learning strategies. "The strength of learners' motivation can be expected to have a causal effect on the quantity of learning strategies they employ". In their study, Oxford and Nyikos (1989, p. 294) found that "the degree of expressed motivation was the single most 
powerful influence on the choice of language learning strategies". Good language learners are motivated (Ushioda, 2008). Yule (1996) comments that students who experience success in language learning are among the highest motivated to learn. Higher-proficiency students are more motivated in language study, "the effort they put into their language learning may enable them to employ a wider range of strategies" (Intaraprasert, 2000, p. 257). In the present study, the students at the higher proficiency level actually reported greater use of reading strategies than the students at the lower proficiency level. This could possibly be explained by their differences of motivation in reading.

The second explanation could be the students' strategic awareness. This could be evidenced by the semi-structured interviews in the present study, in which many students with poor reading proficiency explained that they employed certain strategies infrequently or even did not use them because they were unaware of them or they did not know how to use them. Strategic awareness is critically important in skilled reading. According to Sheorey and Mokhtari (2001, p. 433), "It is the combination of conscious awareness of the strategic reading process and the actual utilization of reading strategies that distinguishes the skilled from unskilled readers". As Paris and Jacobs (1984) point out, skilled readers often engage in deliberate activities that require planful thinking, flexible strategies, and periodic self-monitoring, while novice readers often seem oblivious to these strategies and the need to use them. In accordance, Pressley (2000) suggests that awareness and use of reading strategies is a characteristic of superior reading comprehension and successful reading. Many previous studies have also revealed that higher proficiency readers usually have higher awareness of strategy use (Block, 1986; Najar, 1998; Liu, 2004; Anastasiou \& Griva, 2009; Luo, 2010).

Anastasiou and Griva (2009) found that poor readers were less aware of the more sophisticated cognitive strategies, and they reported using a limited number of meta-cognitive strategies in comparison with good readers. This was similar to the present study, which showed that the students at the higher proficiency level reported employing a wide range of reading strategies significantly more frequently than the students at the lower proficiency level, including the strategies concerning guessing, holistically comprehending the text, seeking key information, regulating or monitoring the reading process. Most of these strategies are metacognition awareness related or sophisticated cognition competence related, which means that the higher proficiency students had higher strategic awareness, and thus employed more strategies than the lower proficiency students.

The third explanation could be the frequency of out-of-classroom reading. In the present study, it was found from the questionnaires and the interviews that the students who reported a higher frequency of reading strategy use also reported a higher frequency of out-of-classroom reading. It could be inferred that the more the students read Business English texts, the more they could employ reading strategies. The students who read Business English more after class would be more experienced in reading Business English and more skillful in employing reading strategies to enhance their reading comprehension and overcome their reading difficulties. The students who read more frequently out of the classroom were actually those students with higher reading proficiency. The study by Intaraprasert (2000) revealed that higher-proficiency students were highly motivated to seek opportunities to expose themselves to English outside the classroom and they were able to employ a wider range of strategies. The study of Luo (2010) also revealed that the students who read English texts frequently out of the classroom reported significantly a higher frequency of strategy use at the overall, category and individual levels than those who read English texts infrequently after class.

Another possible explanation may be the students' English language abilities. According to Ellis (1994), the relationship between students' use of strategies and their levels of language proficiency is bi-directional. Students' use of learning strategies will influence their language proficiency, and in turn their language proficiency will also affect their choices of learning strategies. In the present study, the students with a higher reading proficiency reported significantly more use of reading strategies. This could be interpreted as that the students' greater use of reading strategies enabled them to achieve higher reading proficiency, and conversely their higher reading ability enable them to employ a wider range of reading strategies frequently and effectively. In addition, the good- and the poor-proficiency students preferred to employ different reading strategies due to their different language abilities. For example, good-proficiency students reported employing more strategies relating to language abilities, such as making use of word collocation, analyzing the structures of difficult sentences and analyzing the formation of unknown words, whereas poor-proficiency students tended to employ the reading strategies relating to the dictionaries, references or the help from others to cope with their reading difficulties, such as reading the new word list, looking up the new words in the dictionary, consulting the references or asking teachers or friends for help. 


\section{Conclusion}

This study investigated the relationship between the use of reading strategies by the university Business English majors and their levels of reading proficiency. The results showed that the students with good reading proficiency reported employing reading strategies significantly more frequently than the students with either fair or poor reading proficiency at the overall and category levels. At the individual strategy level, more than half of the reading strategies across the inventory showed significant variations according to the students' levels of reading proficiency. The main variation pattern was positive. The students at the higher proficiency levels employed reading strategies significantly more frequently than the students at the lower proficiency levels. In addition, students at different proficiency levels tended to employ different reading strategies.

The results of the present study revealed that the students with good reading proficiency had much higher strategic awareness than the students with fair or poor reading proficiency, and they were more skillful in employing a variety of reading strategies effectively to comprehend the reading texts. This indicates that the strategic awareness and reading skills of the students with fair and poor reading proficiency, especially the students with poor reading proficiency, need to be improved. The poor readers need to learn from the good readers in the use of reading strategies. The teachers of Business English should help the students increase their strategic awareness, encourage them to employ more strategies and train them to use different reading strategies appropriately and effectively while reading Business English texts.

\section{References}

Adamson, H. D. (1993). Academic competence, theory and classroom practice: Preparing ESL students for content courses. New York: Longman.

Alderson, J. C. (2000). Assessing reading. Cambridge: Cambridge University Press. http://dx.doi.org/10.1017/CBO9780511732935

Anastasiou, D., \& Griva, E. (2009). Awareness of reading strategy use and reading comprehension among poor and good readers. Elementary Education Online, 8(2), 283-297.

Anderson, J. R. (2000). Learning and memory: An integrated approach (2nd ed.). New York: John Whiley. http://dx.doi.org/10.1037/0278-7393.26.5.1141

Anderson, N. J. (1991). Individual differences in strategy use in second language reading and testing. Modern Language Journal, 75, 460-472. http://dx.doi.org/10.1111/j.1540-4781.1991.tb05384.x

Badrawi, N. (1992). The reading dilemma: Meeting individual needs. English Teaching Forum, 30(3), 16-19.

Barnett. M. A. (1988). Reading through Context: How Real and Perceived Strategy Use Affects L2 $\begin{array}{lllll}\text { Comprehension. Modern } & \text { Language }\end{array}$ http://dx.doi.org/10.1111/j.1540-4781.1988.tb04177.x

Block, E. (1986). The comprehension strategies of second language readers. TESOL Quarterly, 20, 463-494. http://dx.doi.org/10.2307/3586295

Brown, A. L. (1989). A Practical Guide to Language Learning. New York: Mc Graw-Hill.

Carrell, P. (1991). Second language reading: Reading ability or language proficiency? Applied Linguistics, 12(2), 159-179. http://dx.doi.org/10.1093/applin/12.2.159

Carrell, P., Devine, J., \& Eskey, D. (1998). Interactive approaches to second language reading. Cambridge: Cambridge University Press.

Cheng, L. (2010). Academic Reading and Strategy Uses. Guangzhou: Zhongshan University Press.

Cogmen, S., \& Saracaloglu, A. (2009). Students' usage of reading strategies in the faculty of education. Procedia Social and Behavioral Sciences, 1, 248-251. http://dx.doi.org/10.1016/j.sbspro.2009.01.045

Ellis, R. (1994). The Study of Second Language Acquisition. Oxford: Oxford University Press.

Fraenkel, J., \& Wallen, N. (2000). How to Design and Evaluate Research in Education. London: The McGraw-Hill Companies.

Goodman, K. (1967). Reading: A psycholinguistic guessing game. Journal of the Reading Specialist, 4, 126-135. http://dx.doi.org/10.1080/19388076709556976

Grabe, W., \& Stoller, F. (2007). Teaching and researching reading. Great Britain: Pearson Education (Longman).

Green, J. M., \& Oxford, R. (1995). A closer look at learning strategies, L2 proficiency, and gender. TESOL 
Quarterly, 29(2), 261-297. http://dx.doi.org/10.2307/3587625

Hosenfeld, C. (1977). A preliminary investigation of the reading strategies of successful and nonsuccessful second language learners. System, 5, 110-123. http://dx.doi.org/10.1016/0346-251X(77)90087-2

Intaraprasert, C. (2000). Language learning strategies employed by engineering students learning English at the tertiary level in Thailand (Unpublished Doctoral Dissertation, School of Education, University of Leeds, England).

Liu, H. J. (2004). The Relationship between the Metacognitive Strategies and Reading Proficiency. Foreign Languages and Their Teaching, 12, 24-26.

Liu, Y. C. (2002). Differences of Reading Strategies Used by the Successful and Unsuccessful Readers. Foreign Language Teaching Abroad, 3, 24-29.

Liu, Y. L., \& Zhang, J. (2008). An Empirical Study of Reading Strategies Employed by Non-English Majors. Taking Students of a College of Guangdong University of Technology as Samples. Joural of Southwest Jiaotong University (Social Sciences), 9(6), 65-70.

Luo, H. F. (2010). English Reading Text Comprehension Strategies by EFL University Students (Unpublished Doctoral Dissertation, School of Foreign Languages, Suranaree University of Technology, Thailand).

Maarof, N., \& Yaacob, R. (2011). Meaning-making in the first and second language: Reading strategies of Malaysian students. Procedia Social and Behavioral Sciences, 12, 211-223. http://dx.doi.org/10.1016/j.sbspro.2011.02.029

Martinez, A. C. L. (2008). Analysis of ESP university students' reading strategy awareness. IBERICA, 15, 165-176.

Mokhtari, K., \& Reichard, C. (2002). Assessing Students' Metacognitive Awareness of Reading Strategies. Journal of Educational Psychology, 2(94), 249-259. http://dx.doi.org/10.1037/0022-0663.94.2.249

Mokhtari, K., \& Reichard. C. (2004). Investigating the strategic reading process of first and second language readers in two different cultural contexts. System, 32, 379-394. $\mathrm{http}: / / \mathrm{dx}$. doi.org/10.1016/j.system.2004.04.005

Najar, R. L. (1998). A study of cognitive learning strategy use on reading tasks in the L2 classroom (On-line). Paper Presented at the AARE 1998 Annual Conference-Adelaide. Retrieved from http://www.aare.edu.au/98pap/naj98081.htm

Oxford, R., \& Nyikos, M. (1989). Variables affecting choice of language learning strategies by university $\begin{array}{lllll}\text { students. } \quad \text { The } & \text { Lodern }\end{array}$ http://dx.doi.org/10.1111/j.1540-4781.1989.tb06367.x

Paris, S. G., \& Jacobs, J. E. (1984). The benefits of informed instruction for children's reading awareness and comprehension skills. Child Development, 55(6), 2083-2093. http://dx.doi.org/10.2307/1129781

Pressley, M. (2000). What should comprehension instruction be the instruction of? In M. Kamil, P. Mosenthal, P. Pearson, \& R. Barr (Eds.), Handbook of Reading Research (vol. 3, pp. 545-561). Lawrence Erlbaum, Mahwah, HJ.

Saengpakdeejit, R. (2009). An employment of Reading Strategies by Science-oriented Students Learning English at the Thai Government Universities (Unpublished Doctoral Dissertation, School of Foreign Languages, Suranaree University of Technology, Thailand).

Sheorey, R., \& Mokhtari, K. (2001). Differences in the metacognitive awareness of reading strategies among native and non-native readers. System, 29, 431-449. http://dx.doi.org/10.1016/S0346-251X(01)00039-2

Song, M. J. (1998). Teaching reading strategies in an ongoing EFL university reading classroom. Asian Journal of English Language Teaching, 8, 41-54.

Taraban, R., Kerr, M., \& Rynearson, K. (2004). Analytic and pragmatic factors in college students' $\begin{array}{lllll}\text { metacognitive reading } & \text { strategies. Reading }\end{array}$ http://dx.doi.org/10.1080/02702710490435547

Urquhart, S., \& Weir, C. (1998). Reading in a second language: Process, product and practice. New York: Longman.

Ushioda, E. (2008). Motivation and good language learners. In C. Griffiths (Eds.), Lessons from Good Language Learners (pp. 19-34).

Cambridge:

Cambridge

University

Press. 
http://dx.doi.org/10.1017/CBO9780511497667.004

Wallace, C. (1992). Reading. Oxford: Oxford University Press.

Yule, G. (1996). The study of Language. Cambridge: Cambridge University Press.

Zhang, L. J., \& Wu, A. (2009). Chinese senior high school EFL students' metacognitive awareness and reading-strategy use. Reading in a Foreign Language, 21(1), 37-59.

\section{Appendix}

\section{Strategy Questionnaire for Business English Reading (SQBER)}

This questionnaire is designed to collect information about the university Business English majors' reading strategy employment when they read their specialized texts. I would like to ask you to do me a favor by answering the following questions concerning how you read business English texts. This is not a test, so there is no "right" or "wrong" answers. The aim of the questionnaire is to collect the personal opinions. I do hope to get your sincere answers. Your answers to the questionnaire will be used for academic research only and will be treated with the utmost confidentiality. Your cooperation and contribution will be very much appreciated.

Instructions: This questionnaire consists of two parts:

\section{Part 1. Personal information}

Part 2. Reading strategy items

Part 1:

Personal information

Please provide your personal information by putting a tick $(\checkmark)$ in the box of the choices given or write the response where necessary.

Your gender: $\square$ Male $\square$ Female

The name of your university:

Academic year of study: $\square$ 1st year $\square$ 2nd year $\square$ 3rd year $\square$ 4th year

You regard your English reading proficiency as:

$\square$ Very good $\square$ Good $\square$ Fair $\square$ Poor $\square$ Very poor

Do you like Business English?

\section{$\square$ Yes $\square$ No}

The frequency of reading Business English out of classroom:

$\square$ Never/Seldom $\square$ Sometimes $\square$ Often $\square$ Every day/almost every day

Part 2:

\section{Reading Strategy Questionnaire}

Instructions: The following statements are the descriptions about Business English reading strategies. Please read each statement carefully and consider how frequently you employ the given strategies while reading Business English. Please mark your response with a " $\checkmark$ " in the corresponding space provided. The answers are just your own opinions and there is no 'right' or 'wrong'. Please give your answers sincerely.

\begin{tabular}{|l|l|}
\hline "Never" & means that you never use the strategy when reading \\
\hline "Sometimes" & means that you occasionally use the strategy when reading \\
\hline "Often" & means that you use the strategy frequently when reading \\
\hline "Always/Almost always & means that you use the strategy most of the time when reading \\
\hline
\end{tabular}


1. Pre-reading Strategies: Before reading Business English texts, do you employ any strategies to help you understand the materials you are going to read? If yes, please specify the frequency

\begin{tabular}{|l|l|l|l|l|}
\hline \multirow{2}{*}{ Statements of the strategies } & Frequency of your own reading strategies use \\
\cline { 5 - 5 } & Never & Sometimes & Often & $\begin{array}{l}\text { Always/Almost } \\
\text { always }\end{array}$ \\
\hline 1. Read the title of the text carefully. & & & & \\
\hline 2. Construct my related knowledge about the topic. & & & & \\
\hline 3. Set goals or purposes of reading. & & & & \\
\hline 4. Read or check the new word list. & & & & \\
\hline 5. Glance over the foot notes, tables and graphics, etc. (if any) & & & & \\
\hline 6. Read the questions about the text. (if any) & & & & \\
\hline 7. Read the first and the last paragraphs. & & & & \\
\hline 8. Skim the text. & & & & \\
\hline 9. Read the first or the last sentence of each paragraph. & & & & \\
\hline 10. Make predictions or inference about the content of the text. & & & & \\
\hline 11. Search for some related information about the topic. & & & & \\
\hline
\end{tabular}

2. While-reading Strategies: While reading Business English texts, do you employ any strategies to enhance your comprehension or solve your reading problems and difficulties? If yes, please specify the frequency

Statements of the reading strategies

(Strategies for comprehending the text)

12. Pay attention to the key words in the text.

13. Use specialized terms as clues or indications.

14. Search for the topic sentence of each paragraph.

15. Read every word and sentence slowly and carefully.

16. Confirm my predictions or inference.

17. Ask myself questions about some information in the text.

18. Make use of features of the text (e.g. notes, tables and italics).

19. Consider the logic, coherence and consistency of the textual information.

20. Draw on my prior knowledge of the topic.

21. Take notes or mark the important information in the text.

22. Pause and think about what I am reading from time to time.

23. Skip or neglect the unneeded or unimportant content.

24. Do fast reading first and peruse later.

25 . Analyze the formations of the unknown words.

26. Guess the meanings of the words or the sentences from the context.

27. Analyze the structures of difficult sentences.

28. Adjust reading rate according to the difficulty of 


\begin{tabular}{|l|l|l|l|l|}
\hline different parts & & & & \\
\hline 29. Ask the teachers, classmates or friends for help. & & & & \\
\hline 30. Translate the text into Chinese. & & & & \\
\hline 31. Make use of word collocations. & & & & \\
\hline 32. Consult the dictionary for new words. & & & & \\
\hline 33. Reread the difficult parts. & & & & \\
\hline 34. Skip the new words or difficult sentences. & & & & \\
\hline $\begin{array}{l}\text { 35. Consult references to solve reading problems or } \\
\text { difficulties. }\end{array}$ & & & & \\
\hline
\end{tabular}

3. Post-reading Strategies: After reading Business English texts, do you employ any strategies to help you understand the texts better? If yes, please specify the frequency

\begin{tabular}{|l|l|l|l|l|}
\hline \multirow{2}{*}{ Statements of the strategies } & \multicolumn{2}{l}{ Frequency of your own reading strategies use } \\
\cline { 4 - 5 } & Never & Sometimes & Often & $\begin{array}{l}\text { Always/Almost } \\
\text { always }\end{array}$ \\
\hline $\begin{array}{l}\text { 36. Make critical comments and evaluations on the content of } \\
\text { the text. }\end{array}$ & & & & \\
\hline 37. Look up the new words in the dictionary & & & & \\
\hline 38. Reflect or evaluate my reading performance and results. & & & & \\
\hline 39. Summarize what I read. & & & & \\
\hline 40. Review the content of the text. & & & & \\
\hline 41. Read other resources about the same topic. & & & & \\
\hline 42. Review the notes and marks I made. & & & & \\
\hline 43. Conclude my reading problems/difficulties. & & & & \\
\hline 44. Summarize the mistakes I made. & & & & \\
\hline $\begin{array}{l}\text { 45. Discuss the problems and difficulties with teachers or } \\
\text { friends. }\end{array}$ & & & & \\
\hline 46. Apat from the stang & & & & \\
\hline
\end{tabular}

46. Apart from the strategies mentioned above, are there any strategies that you employ when you read Business English? Please identify:

Thank you very much for your cooperation!

\section{Copyrights}

Copyright for this article is retained by the author(s), with first publication rights granted to the journal.

This is an open-access article distributed under the terms and conditions of the Creative Commons Attribution license (http://creativecommons.org/licenses/by/3.0/). 